\title{
The fertile grounds initiative: a concerted action for integrated soil fertility management
}

\begin{abstract}
Low soil fertility is one of the main factors causing low agricultural productivity in many developing countries. Despite the introduction, implementation and proof of effectiveness of Integrated Soil Fertility Management (ISFM) as the most appropriate approach to alleviate soil fertility constraints in agriculture soil fertility issues remain a key bottleneck. A key element of ISFM is the integrated use of organic and mineral fertilisers. This study shows that widespread implementation of ISFM is currently hampered by different paradigms (e.g feed the plant versus feed the soil), market mechanisms (e.g. push versus pull) and operational scales (e.g. local scale versus global scale) between actors in the organic and mineral fertiliser sectors. To solve this, implementation of ISFM needs to be facilitated through a platform in which suppliers of organic and mineral fertilisers make arrangements for on-farm application of organo-mineral fertilisers based on locally available organic sources supplemented with mineral fertilisers. In this paper we present the motivation behind two case studies in Ethiopia and conclude that institutional barriers and misconceptions about quantity and quality of compost are currently hampering wide-spread application of the approach.
\end{abstract}

Keywords: Africa; Fertiliser; Stakeholders; Soil nutrients; Interventions
Volume 6 Issue 3 - 2017

\author{
Christy van Beek,' Niek van Duivenbooden,' \\ Nadine Herold,' Aad Kessler, ${ }^{2}$ Paul Römkens' \\ 'Senior scientist Wageningen Environmental Research, The \\ Netherlands \\ ${ }^{2}$ Assistant professor Wageningen University, The Netherlands
}

\begin{abstract}
Correspondence: Christy van Beek, Senior scientist Wageningen Environmental Research, Droevendaalsesteeg 101 , 6700 AA, Wageningen, The Netherlands, Tel +313-174-865-26, Email christy.vanbeek@wur.nl
\end{abstract}

Received: January 02, 2017| Published: February 06, 2017

\section{Introduction}

Sub-Saharan Africa (SSA) is a rapidly developing and its' population is projected to reach around 2.1billion by Population Reference Bureau ${ }^{1}$ of the total population, around $63 \%$ currently lives in rural areas $^{2}$ where agriculture is their main source of livelihood. Smallholder farmers are the primary producers of agricultural outputs and account for about $80 \%$ of all farms in SSA. ${ }^{3}$ Despite gradual growth of the agricultural sector, productivity levels, especially when expressed per unit of land, are still far below global averages. ${ }^{4}$ Low soil fertility is one of the main causes of low agricultural productivity in SSA leading to social instability in general and food insecurity in particular. Soil fertility decline is caused by various natural and anthropogenic factors. Natural factors include erosion, gaseous losses, runoff and leaching, which can be aggravated by anthropogenic factors like intensive cropping and poor land management. To halt soil fertility decline and to improve the productive capacity of land many concepts have been developed and tested. Vanlauwe ${ }^{5}$ provides a comprehensive overview, highlighting the different concepts through time. However, to our view, all these concepts had one key limitation, i.e. the brokerage of nutrients between stakeholders. In this paper we argue that brokerage of nutrients between stakeholders is a prerequisite for adoption of interventions to improve soil fertility levels and that so far the limited inclusion of stakeholders has limited the impacts of previous attempts to improve soil fertility levels in SSA.

During the past decades numerous interventions, concepts and approaches have been introduced to increase the productive capacity of soils. Some of these interventions specifically addressed ISFM, others aimed at 'kickstarting' improved nutrient management with a more indirect contribution to ISFM. Basically, all approaches can be subdivided into two distinct groups:
I. Interventions aiming at increasing the amounts of nutrients in soil through promoting the use of organic and mineral fertiliser and

II. Interventions aiming at increasing the use efficiencies of nutrients already existing in the soil. Interventions aiming at increasing the amount of nutrients in soil through import of organic and mineral fertilisers can be further subdivided into:

a) Large-scale initiatives designed to increase the supply of fertiliser, and

b) Small-scale demonstration sites designed to show the benefits of more efficient fertiliser use, as such increasing the demand of fertilisers by farmers. Examples of approaches addressing the increase in supply include e.g. market reform programmes and fertiliser vouchers systems like the one introduced in Malawi. ${ }^{6}$ Examples of projects aiming to increase the awareness about and demand for fertiliser include demonstration sites, like the FAO or NGOs are frequently promoting. ${ }^{7,8}$ In these sites the benefits of organic and mineral fertilisers are demonstrated to farmers. Often, farmers are involved in the management of the demonstration site. The sites can be located at research stations, demonstration farms, communal grounds or at the farmers own land.

Interventions targeting an improved efficiency of resources do not replenish removed nutrients, but rather aim to maintain or release nutrients from the soil stock, by means of e.g. soil amendments with micro-starters, liming, etc. These interventions are based on the release of nutrients through increased mineralization by manipulating the conditions for soil microbes, or on shifts in the adsorption complex of P by manipulating the soil $\mathrm{pH}$. Each approach also has its shortcomings as is schematically shown in Table 1. The subdivisions of the approaches listed in Table 1 are elaborated in more detail in the following section. 
Table I Tabular review of past approaches to address soil fertility

\begin{tabular}{llll}
\hline & Soil fertility interventions & & \\
Main Groups & Increase Total Amount Of Nutrients & Increase Availability Of Existing Nutrients \\
Sub-groups & Increase supply of nutrients & $\begin{array}{l}\text { Increase demand for } \\
\text { nutrients }\end{array}$ & $\begin{array}{l}\text { Increase nutrient holding } \\
\text { capacity }\end{array}$ \\
$\begin{array}{l}\text { Example of sub- } \\
\text { group }\end{array}$ & $\begin{array}{l}\text { Market reforms, fertiliser } \\
\text { vouchers }\end{array}$ & $\begin{array}{l}\text { On-farm } \\
\text { demonstrations } \\
\text { nain shortcomings }\end{array}$ & $\begin{array}{l}\text { Mulching, cover crops, } \\
\text { SWC measures }\end{array}$ \\
Limited ownership, expensive & $\begin{array}{l}\text { Islands of success, } \\
\text { limited scalability }\end{array}$ & Soes not resolve nutrient depletion, no replenishment
\end{tabular}

Interventions, concepts and approaches to improve soil fertility

Each of the approaches shown in Table 1 has its success stories, but also its limitations. More importantly, neither of them was able to solve the issue of soil fertility decline on its own.

\section{Interventions that increase the supply of nutrients}

Although the use of mineral fertilisers in SSA is steadily growing, it is still insufficient to supply the estimated requirements by crops (e.g. $\left.{ }^{9}\right)$. A commonly reported bottleneck with regard to the use of mineral fertilisers is the high price of fertilisers. In SSA, which relies on import of inorganic fertiliser, prices of fertilisers are at least $30 \%$ higher (far higher for inland locations) compared to e.g. Thailand, which also imports most of its fertilizers. ${ }^{10}$ The main reason is the high shipping costs (approx. $20-40 \%$ of the price in the farm shops) and inland transportation costs. To overcome the high farm-gate prices of fertilisers one can either remove trade barriers or subsidize fertiliser use. Those in favour of subsidized fertiliser supply often refer to the example of Malawi, where farmers buy fertiliser vouchers at reduced costs and exchange them for fertilisers at a private firm or distributor who can redeem the voucher at a designated government facility. Although implementation of this voucher-based system resulted in increased yields, abuse of the system has also been reported. In addition increased supply often resulted in reduced nutrient use efficiency, resulting in a loss of nutrients. One of the reported jeopardies of the voucher system is that wealthier farmers are in a better position to take advantage of the subsidies and partly exclude other smallholders. Furthermore, costs are high, and it is hard to justify to use up to $28 \%$ of the public expenditures on fertilizers. ${ }^{11}$ Modified voucher systems that specifically target the rural poor and stimulate private inputs are called smart subsidies and include an exit strategy that gradually reduces the value of the voucher. ${ }^{12}$ These approaches still have to prove themselves. Fertiliser voucher programmes can contribute to economic development in poor rural economies provided that these subsidies target market failures in, for example, access to knowledge, input or capital and are accompanied with capacity building programmes for farmers to prevent misuse of fertilizers. ${ }^{6}$ The large-scale initiatives that are part of this group of interventions can be successful but often tend to be expensive and lack the sense of ownership among farmers

\section{Interventions that increase the demand for nutrients}

Numerous demonstration trials with different combinations of crops and fertilisers have been carried out over the past decades.
Especially the FAO embraced this approach and implemented more than 1385 demonstration trials since $1969 .^{7}$ Also NGOs frequently adopt this approach because of its visibility and sympathy with the local community. The demonstration fields may be part of a farmer field school, or a special learning farm may be used. Through demonstration days farmers are encouraged to use certain practices, e.g. ISFM. These local demonstrations are often very much appreciated by the farmers and respect local agro-ecological contexts. However, once farmers wish to adopt the demonstrated practices, the supply of e.g. organic and mineral fertilisers may become limiting and results are difficult to scale up. Therefore, approaches in this group have a tendency to remain islands of success with limited impacts outside their direct zone of intervention.

\section{Interventions that increase the nutrient holding capacity of the soil}

This group of interventions contains an array of practices including soil and water conservation (SWC) measures like mulching, construction of soil bunds and/or terraces, etc. These approaches commonly stem from conservation purposes to halt erosion and are typically applied at a relatively large scale (e.g. at catchment scale) to enhance their impact. Nutrient balance calculations indeed reveal that erosion is a main factor in many smallholder farming systems leading to nutrient $\operatorname{losses}^{13}$ and SWC measures therefore should be an integral part of soil fertility interventions.

\section{Interventions that increase the release of native nutrients}

Intervention measures that belong to this group are soil amendments like 'compost starters' or 'soil primers'. These products often contain (combinations of) bone meal, peat, coffee grounds, compost, coir, manure, straw, vermiculite, sulphur, blood meal, and/ or rock fertilisers which are believed to revitalize microbial activity. The proof of these amendments however is limited and as Himanen and Hänninen ${ }^{14}$ concluded is often the result of the nutrient contents of the product itself. Also, physical interventions that increase the aeration of the soil can contribute to the release of nutrients through increased mineralization. Aeration, micro-organisms and liming all increase mineralization of soil organic matter and hence release nutrients for crop uptake. Aeration, micro-organisms and liming all increase mineralization of soil organic matter and hence can result in an increased release of nutrients to be taken up by crops.

In Table 2 an overview of the different approaches is presented, including main philosophy, outcomes and limitations. Notably, all types of interventions are needed to develop highly performing, high efficiency food production systems. Yet, the different types of 
interventions are often introduced in isolation. We argue that there is no silver bullet. Rather, there are various ways to improve soil fertility that all have specific requirements for success. The challenge is to integrate the different approaches into the right package of interventions for a specific situation, as none of these interventions, concepts or approaches will solve the problem of low soil fertility on its own.

Table 2 Characteristics of main approaches to address soil fertility

\begin{tabular}{|c|c|c|c|c|}
\hline & I a. Increase supply & Ib. increase demand & $\begin{array}{l}\text { 2a. increase nutrient } \\
\text { holding capacity }\end{array}$ & $\begin{array}{l}\mathbf{2 b} \text {. increasing } \\
\text { release }\end{array}$ \\
\hline Change philosophy & $\begin{array}{l}\text { Soil fertility increases } \\
\text { through increasing } \\
\text { the supply of mainly } \\
\text { mineral fertilisers }\end{array}$ & $\begin{array}{l}\text { Soil fertility increases when } \\
\text { farmers become acquainted } \\
\text { with improved practices of } \\
\text { apply organic and mineral } \\
\text { fertilisers }\end{array}$ & $\begin{array}{l}\text { Nutrients are lost from the } \\
\text { system through erosion } \\
\text { and leaching. By increasing } \\
\text { the NHC nutrients are } \\
\text { maintained in the system. }\end{array}$ & $\begin{array}{l}\text { Nutrients are kept in } \\
\text { the soil and can be } \\
\text { released to become } \\
\text { available for crop } \\
\text { uptake. }\end{array}$ \\
\hline
\end{tabular}

\begin{tabular}{|c|c|c|c|c|}
\hline Typical examples & $\begin{array}{l}\text { Market reform } \\
\text { programmes (e.g. } \\
\text { Kenia), fertiliser } \\
\text { voucher programmes } \\
\text { (e.g. Malawi) }\end{array}$ & $\begin{array}{l}\text { Demonstrations at } \\
\text { experimental farms, field } \\
\text { trials at farmer fields. }\end{array}$ & $\begin{array}{l}\text { Mulching, cover crops, no or } \\
\text { limited tillage, green manure, } \\
\text { terracing, contour ploughing. }\end{array}$ & $\begin{array}{l}\text { Soil amendments, } \\
\text { micro-starters, liming }\end{array}$ \\
\hline Operational scale & National & Farm & Field to watershed & Field \\
\hline Advocates/origin & WB, private sector & FAO and NGOs & FAO and NGOs & Private sector \\
\hline Main outcomes & Yields increase & $\begin{array}{l}\text { Awareness of farmers on soil } \\
\text { fertility increases }\end{array}$ & $\begin{array}{l}\text { Erosion and leaching reduce. } \\
\text { Sometimes also volatilization } \\
\text { reduces. }\end{array}$ & Unclear \\
\hline Main limitations & $\begin{array}{l}\text { Limited ownership of } \\
\text { farmers, bias to better- } \\
\text { off farmers, corruption } \\
\text { and veiled interests }\end{array}$ & $\begin{array}{l}\text { When supply chain problems } \\
\text { are not addressed results are } \\
\text { difficult to scale }\end{array}$ & $\begin{array}{l}\text { No replenishment of } \\
\text { removed nutrients }\end{array}$ & $\begin{array}{l}\text { Depletion may be } \\
\text { increased, many } \\
\text { unproven practices }\end{array}$ \\
\hline
\end{tabular}

\section{Stakeholders in soil fertility management}

Soils are a common good in the sense that it's a shared responsibility of humanity to look after the sustainable soil management. Indeed, several international organizations e.g. FAO and UNCCD, have adopted soil fertility in their action agenda, Also soil is frequently mentioned in the Sustainable Development Goals (www.un.org). However, being a common good, soil has value for many, but ownership of a few. The current opinion is that for institutional sustainability the intervention to increase in soil fertility should be profitable, preferably for a capital intensive actor ${ }^{15}$ and nowadays, even calls from once purely development oriented donors require a solid business case. This easily leads to the question in whose interest soil fertility interventions are taken. The answer may not be as obvious as it sounds and include farmers, private sectors, companies and NGOs. Although these actors all have a stake in soil fertility their position may be quite different as is schematically shown in Table 3 .

Table 3 Main actors and interests in soil fertility management

\begin{tabular}{|c|c|c|c|c|c|}
\hline & Farmers & $\begin{array}{l}\text { Fertiliser } \\
\text { industry }\end{array}$ & Organic industry & Government & Ngos \\
\hline Interest & $\begin{array}{l}\text { High productive } \\
\text { soils }\end{array}$ & $\begin{array}{l}\text { Sales of mineral } \\
\text { fertilisers }\end{array}$ & $\begin{array}{l}\text { Sales of organic } \\
\text { fertilisers }\end{array}$ & $\begin{array}{l}\text { Achieve food } \\
\text { security }\end{array}$ & $\begin{array}{l}\text { Environmental } \\
\text { conservation }\end{array}$ \\
\hline $\begin{array}{l}\text { Operational } \\
\text { scale }\end{array}$ & Plot and Farm level & $\begin{array}{l}\text { Global and } \\
\text { Regional }\end{array}$ & $\begin{array}{l}\text { National and } \\
\text { district }^{1}\end{array}$ & $\begin{array}{l}\text { National and } \\
\text { district }\end{array}$ & $\mathrm{All}{ }^{2}$ \\
\hline $\begin{array}{l}\text { Willingness } \\
\text { and ability to } \\
\text { pay }\end{array}$ & Limited & To some extent & To some extent & Variable & $\begin{array}{l}\text { Depending on funding } \\
\text { and visibility }\end{array}$ \\
\hline $\begin{array}{l}\text { Main } \\
\text { bottleneck }\end{array}$ & $\begin{array}{l}\text { Land tenure } \\
\text { systems may } \\
\text { not stimulate } \\
\text { investments in soil } \\
\text { fertility. }\end{array}$ & $\begin{array}{l}\text { Face limited } \\
\text { investment } \\
\text { potential from } \\
\text { small-holder } \\
\text { farmers }\end{array}$ & $\begin{array}{l}\text { Limited supply, } \\
\text { dispersion of } \\
\text { contaminants }\end{array}$ & $\begin{array}{l}\text { Competing } \\
\text { interests with } \\
\text { regard to land } \\
\text { policies }\end{array}$ & $\begin{array}{l}\text { Many NGOs rely on } \\
\text { public fund raising and } \\
\text { soil is generally not } \\
\text { considered very attractive }\end{array}$ \\
\hline
\end{tabular}

i. District or provincial depending on the country.

ii. There are NGOs at various scales going from local (village) scale to international scales. 


\section{Farmers}

In SSA countries, farmers developed their knowledge and learned to manage their soils by generations of experience and experimentation with the soil. ${ }^{16}$ However, farmers perception of soil fertility and indicators they use to assess the fertility status of their fields may differ very much from the scientific view on soil fertility and indicators used. In a study of Gray et al., ${ }^{17}$ scientific measures of soil fertility were related to farmers' perceptions of soil types and changing soil fertility in a small village in south western Burkina Faso. While farmers' perception of soil types and characteristics matched up very well with scientific examinations, the actual perception of soil degradation differed. Other authors ${ }^{18,19}$ expressed that farmers see the soil fertility not only as function of different soil characteristic they observe, but also as a result of human management; researchers consider soil fertility as a combination of measurable soil parameters only. This shows that farmers can perceive differences in the soil fertility at farm level, but that it is important to investigate how farmers' perceptions are based on other concerns and how various physical, economic and socio-cultural factors interact. Hence, in order to design more appropriate research and soil fertility interventions with the intend to improve nutrient management and increase soil fertility, understanding the local knowledge of soils, farmer perceptions of soil fertility and farmers' soil management practices has come to be seen as essential for the success of agricultural development. ${ }^{20,21}$

Farmers, obviously, have a very direct interest for fertile soils, but adoption of improved practices is often limited (i.e. less than $10 \%$, e.g. ${ }^{22}$ ). Amsalu et al..$^{23}$ showed that farm household conditions (e.g. family size, presence of livestock, age of the household head and education level) and profitability are key determinants for adoption of soil and water conservation measures in Ethiopia. Also labour requirements ${ }^{24}$ and land tenure ${ }^{22,25}$ are key parameters for adoption of soil fertility interventions.

\section{Mineral Fertilisers}

The fertiliser industry plays an important role in the global nutrient cycle; it is their business and the industry controls the accessibility (price and presence) and quality (composition) of the fertilisers. . With regard to $\mathrm{N}$ fertilisers, the industry can be characterised both as a global but also highly scattered industry. Notably, the largest companies have less than $5 \%$ of the production capacity, but their market share seems to be increasing. ${ }^{26}$ For some civil society organizations this is an argument to control global nutrient trade very carefully. They refer to the seed industry, where a limited number of companies dominate the sector, which according to these organization lead to dependency and exploitation of farmers. For $\mathrm{P}$ and $\mathrm{K}$ fertilisers the situation is different and both $\mathrm{K}$ and $\mathrm{P}$ fertiliser industry is largely a mining industry with a limited number of sites. Currently, about 1000 companies with some 2000-3000 production sites produce about 360 million tonnes fertilisers per year. Some fertiliser companies have a well-developed view on agricultural development, where most of them refer to the judicious use of fertilisers and the $4 \mathrm{R}$ approach of right timing, right product, right application and right rate of the Nutrient Stewardship (http://www.nutrientstewardship.com/). Most fertiliser companies provide support to farmers through training and decision support tools (e.g. SMS services). In the end the purpose is to increase the fertiliser consumption (through type 1A and 1B interventions of Table 1).

\section{Organic fertilisers}

Organic wastes may prove a valuable source of nutrients to replenish soil fertility. Bio-waste conversion technologies are already implemented in Africa; compost production from bio-waste fractions is widely accepted in Africa as a best practice (especially in agricultural areas) and the widespread adoption of manure-to-biogas technologies have paved the way for bio-waste-to-biogas technologies to become accepted and implemented in Africa. The largest challenge to recycle bio-waste in Africa is to make it cost efficient and to create sufficient capacity for environmentally sound bio-waste management, which is currently hampered by inadequate or limited awareness and appreciation of best practices for environmentally sound management, access to finance and technological know-how. ${ }^{27}$

\section{Governments}

ISFM can only work when supported by governments that are responsible for fertiliser imports, an enabled extension service that is critical to delivering the technology to the farmers, as well as a vibrant agro-dealer private sector that ensures efficient fertiliser and seed availability and distribution..$^{28}$ Other roles for governments are to stimulate research on ISFM especially related to climate change, and create an enabling context where ISFM can flourish with infrastructure, subsidies, and regulations. Fertiliser prices generally decrease and output prices increase with improvements in roads, ports, and the removal of tariffs and rent-seeking activities by traders, issues that are requiring concerted efforts by governments. ${ }^{28}$ The government of Burkina Faso and Ghana were the first ones with a national integrated soil fertility plan, but due to limited funds execution of this could not take place..$^{29}$ Also Nkonya ${ }^{30}$ states in her blog that two of the reasons for African farmers not to adopt ISFM practices are agricultural extension agents not having sufficient capacity to advise farmers on ISFM (and climate smart agriculture) and governments not investing in developing and supporting them.

\section{Non-governmental organizations}

Non-governmental organizations can perform projects on soil fertility and land quality. Often these projects originate from a food security perspective (e.g. FAO, AGRA) or from an environmental conservation perspective (e.g. UNCCD). Their main concern is the limited appeal of soil for their supporters. Soil fertility decline is hardly visible and restoration takes years.

\section{Integrating the approaches: the fertile grounds initiative}

The promotion of chemical fertilisers to boost agricultural production in areas with low soil fertility has been subjected to long and intense debates. The debate is intense, because of the commercial interests connected to chemical fertilisers, the political commitment to higher inputs in agriculture, the ideological debate between subsidies and liberalization, and the discussion between advocates of industrial agriculture versus organic or ecologically based agricultural production systems. Yet, both approaches are needed: Some 'natural' soil deficiencies need to be compensated for with mineral fertilisers to sustain sufficient food production. The organic approach stressing the recycling of nutrients and organic matter is necessary to sustain sufficient organic matter levels for a healthy and fertile soil, and to prevent high input investments, particularly in remote areas.

The Fertile Grounds Initiative (FGI) is a concerted strategy of collaboration between actors in nutrient management at various spatial and institutional scales. It is based on bringing together supply and demand of nutrients within a specific geographical area, to 
process these and to make optimum use of site-specific interventions and available nutrients, supplemented with external imports. Better use and distribution of available nutrient sources will increase nutrient use efficiencies at field and farm scales which is fundamental in FGI. FGI comprises 8 components aiming at better nutrient management with the intent to increase soil fertility and thus to enhance food and economic security. This approach needs to be adapted to local conditions and single components will be executed simultaneously.

The first two components include the inventory of nutrient requirements (demand of farmers) and the inventory of nutrient availability (supply at different scales); together they form what can be called the nutrient gap analysis. Essential for the following-up steps are institutional willingness and concerted alignment of a variety of actors and stakeholders at various levels of scale. While component
III focuses on producing integrated fertiliser products (product formulation and processing), component IV is bringing together supply and demand of nutrients and developing arrangements for trade (brokering). Component $\mathrm{V}$ deals with optimization of nutrient trade and transport to ensure a well-organized nutrient supply (Trade logistics). In addition to component VI, i.e. capacity building, component VII (Institutionalization) promotes institutional arrangements regarding cooperatives, nutrient banks, legal and institutional embedding. FGI also recognizes the importance of an enabling environment (component VIII) that should mobilise support for market access, micro-credits, insurances, etc. for smallholder and other farmers. As a concept FGI also aims to facilitate upscaling of results obtained and provide support to policy making. The 8 components can be grouped in 3 result areas, viz. nutrient gap assessment, platform and scaling as is shown in Table 4.

Table 4 The 8 components of the FGl approach and the tools used

\begin{tabular}{llll}
\hline Component & Tools and methods & Result area \\
\hline I & Quantify demand & QUEFTS, MonQI & \\
II & Quantify supply & Surveys, analysis of composting fractions, MonQI & Nutrient gap assessment \\
III & Product formulation & Difference between I and II & \\
IV & Brokerage & Stakeholder platform & Platform \\
V & Trade logistics & Business case formulation & \\
VI & Capacity building & Workshops, training, courses & Scaling \\
VII & Institutionalization & Case specific & \\
VIII & Enabling environment & Case specific & \\
\hline
\end{tabular}

Table 5 Costs and revenues of soil fertilization strategies according to Business as Usual and the FGl approach

\begin{tabular}{|c|c|c|c|}
\hline & & $\begin{array}{l}\text { Business as usual, mostly mineral } \\
\text { fertiliser with on-farm compost }\end{array}$ & $\begin{array}{l}\text { FGI approach, } \\
\text { mostly organic fertiliser from on-farm } \\
\text { and off-farm, supplemented with mineral } \\
\text { fertilisers }\end{array}$ \\
\hline \multirow{4}{*}{$\begin{array}{l}\text { Producer } \\
\text { costs }\end{array}$} & Waste collection & n.a. & $\begin{array}{l}\text { Collection and transport of waste to composting } \\
\text { facility, }\end{array}$ \\
\hline & $\begin{array}{l}\text { Compost } \\
\text { preparation }\end{array}$ & n.a. & $\begin{array}{l}\text { processing and handling costs, service costs, } \\
\text { equipment, buildings and operational costs }\end{array}$ \\
\hline & Brokerage & Retailers, fertiliser shops & Personnel costs, transaction costs \\
\hline & Transport & Car rent, fuel, up till distribution centre & Car rent, fuel, up till farm gate \\
\hline \multirow{2}{*}{$\begin{array}{l}\text { Farmer } \\
\text { costs }\end{array}$} & Fertiliser purchase & About $20 \%$ of farm income & $\begin{array}{l}\text { Depending on CDM of compost facility, saving on } \\
\text { mineral fertiliser }\end{array}$ \\
\hline & Application costs & $\begin{array}{l}\text { Limited labour costs because of high } \\
\text { concentration }\end{array}$ & $\begin{array}{l}\text { Increased labour costs because of bulkiness of } \\
\text { product. }\end{array}$ \\
\hline \multirow{3}{*}{$\begin{array}{l}\text { Societal } \\
\text { costs }\end{array}$} & Waste disposal & Waste remain untreated and left to rot & Waste used \\
\hline & $\begin{array}{l}\text { Greenhouse gas } \\
\text { emissions }\end{array}$ & $\begin{array}{l}\text { GHG emissions increase, especially under } \\
\text { anaerobic conditions }\end{array}$ & GHG decrease \\
\hline & Resource utilization & $\begin{array}{l}\text { Nutrient recoveries at regional scale } \\
\text { often less than } 10 \% \text {, linear economy }\end{array}$ & $\begin{array}{l}\text { Nutrient recoveries increase, more circular } \\
\text { economy }\end{array}$ \\
\hline
\end{tabular}




\section{Quantitative Evaluation of Fertility of Tropical Soils (QUEFTS)}

Step I of the FGI approach is about determining the nutrient requirements to reach a certain yield and a certain level of soil fertility. The total demand for nutrients is estimated using the QUEFTS model. QUEFTS is a semi-mechanistic model to estimate nutrient requirements for specific soil-crop combinations. QUEFTS estimates the yield based on the indigenous soil nutrient supply, increased with fertilization if required, and a simple crop uptake-yield model including bi-nutrient interactions. QUEFTS was first developed and applied by Janssen (1990) and was recently extended with water and micro-nutrients (Heinen et al., ${ }^{14}$ submitted).

\section{Monitoring for Quality Improvement (MonQI)}

After the determination of the total demand, the current practices and on-farm availability of organic fertilisers is assessed using the MonQI toolbox. MonQI is a methodology and software package for monitoring management and performance of small scale farming systems world-wide. ${ }^{13}$ In FGI MonQI is applied to monitor current fertiliser management, yield levels and soil nutrient balances. The outcomes of QUEFTS and MonQI together provide the nutrient gap, i.e. the difference between the total requirements (estimated with QUEFTS) and the available nutrients (determined with MonQI).

\section{Financial Viability of FGI}

The components of FGI are not new. What's new is the integration of the previously separate worlds of input supplies, local interventions and recycling of nutrients. We expect that this will increase the use of nutrients, their efficiency and, most importantly, volumes of agricultural produce. A key element for success is the economic viability of the FGI approach. At the long run soil fertility interventions are almost always profitable, especially when expressed on a per land unit basis. ${ }^{31}$ Typically, value to costs ratios (VCR) for fertiliser interventions range between 1.6 and 3.6 for dry land regions and tend to be higher in more water secure areas. VCRs higher than 1.5 were found to be a threshold for adoption of the fertilization strategy by farmers. ${ }^{32}$ However, on a short-term basis, profitability is highly dependent on other constraining factors like rainfall, weed infestation and site specific soil conditions. ${ }^{31,32}$ However, these studies focus on the profitability at the farm level and consider a.o. labour costs and purchase of fertilisers. To make a transition towards regional recycling of wastes and integration of different sources of nutrients, a different approach has to be followed in which purchase and performance of fertilisers in a farm shop are compared to regional re-allocation and re-use of nutrients as proposed in the FGI approach.

Couth et al., ${ }^{33}$ showed that waste management through composting is financially viable in large parts of Africa, but only when this is part of the Clean Development Mechanism (CDM), i.e. receive external funding. Also, Onduru et al., ${ }^{34}$ showed that it is technically feasible to produce compost out of organic waste streams, but that current financial barriers hinder large scale adoption in Nairobi.

However, where studies tend to focus on either the profitability at farm level or on the profitability at the composting facility, FGI intends to make the linkages between the farm and the composting plant. For this linkage transport costs of compost to the farmer field is expected to be a crucial factor. At present farmers spend about $20 \%$ of their farm income to fertilizers. ${ }^{31}$

\section{Two case studies in Ethiopia}

The FGI approach is tested in several case studies in SSA. Here we highlight two examples from Ethiopia which demonstrate two contrasting cases. Case studies are typically existing projects in which one or more of the FGI components is already present and to which additional activities are added to make it a fully operational FGI case study. The case studies are selected by national taskforces, in which representatives from governments, NGOs and research organisation give guidance to the project. At present (2016) FGI taskforces are operational in Uganda, Burundi and Ethiopia.

\section{Ziway case study}

In the Ziway area composting is a common way of treating organic resources. At the site of SME (Soil and More Ethiopia) up to 250 tons of fresh organic matter is being recycled daily producing compost. At present the use of compost by farmers in the surrounding areas is however still limited due to both a lack of appreciation of the added value of compost in the fertilization scheme of the farm and a negative perception of the quality of compost. Hence the development of a trading system to enhance nutrient recycling still needs to be developed. At present relatively small amounts of compost are being traded partially based on external support from a local NGO. In the Ziway case study FGI will first focus on the quality of the compost and the perception of farmers, before going into nutrient brokering and subsequent steps of Table 3 .

\section{Adet case study}

In the Adet case study farmers are motivated to produce organic wheat. However, the area is rather remote and concern exists about the availability of sourcing material for compost. A first review revealed that about $93 \mathrm{~kg} \mathrm{~N} / \mathrm{ha}$ and $35 \mathrm{~kg} \mathrm{P} / \mathrm{ha}$ are required to double current yield level (based on CASCAPE data, www.cascape.info), whereas about 2 tonnes/ha of compost is potentially available, which roughly contains $20 \mathrm{~kg} \mathrm{~N} / \mathrm{ha}$. In this case, the role of FGI is on providing best packages of organic fertilisers amended with externally sourced mineral fertilisers.

\section{Discussion and conclusion}

The FGI approach holds the potential to generate considerable impact in terms of scaling-up ISFM. It gives guidance to the wish, or necessity, to increase nutrient efficiencies at several levels of scale. Yet, challenges are on the way. For instance, in Ethiopia compost facilities cope with the problem that there is no official benchmark for compost, which hinders their institutional and operation effectiveness. Other barriers include vested interests and paradigms of different sectors, e.g. the organic fertiliser sector and the mineral fertiliser sector. Policy makers are generally willing to support the FGI approach because of its multiple benefits, but for instance a project on city waste collection for composting did not make it as a case study in Ethiopia?, because this was part of the Ministry of Urban Housing whereas compost application to farmer fields is under the Ministry of Agriculture. Such barriers need to be overcome, but these need time and political willingness. Lastly, compost is not a miracle product. The farmers in Ziway for instance have good reasons to reject applying compost: they fear distribution of contaminants. Mensah et al. (2001) showed the risk of spreading contaminant through compost application for Kumasi and Accra. Most prominent contaminants are pathogens, heavy metals and pesticide residues. Of these, pathogens can be handled through proper compost preparation, but for heavy metals and 
pesticide residues, careful monitoring of original of compost material, compost quality and related application schemes are required.

In conclusion, recent experiences with FGI presented in this paper show that the FGI approach holds the potential to link the waste processing and fertiliser industries (both organic and mineral) with on farm soil fertility management. Many challenges are still ahead and the coming years will tell if the approach can actually kick-start the brokerage of nutrients at several levels of scale. However, FGI can be the catalyst that is urgently needed to save soil nutrients from spillage, reduce wastes, increase recycling and hence contribute to the transition towards a more circular economy. ${ }^{35-37}$

\section{Acknowledgements}

This research was funded by the Netherlands Ministry of Economic Affairs and by the Netherlands Ministry of Foreign Affairs.

\section{Conflict of interest}

The author declares no conflict of interest.

\section{References}

1. PRB (Population Reference Bureau). World Population Data Sheet; 2015.

2. World Bank; 2014.

3. Wiggins S. Can the smallholder model deliver poverty reduction and food security for a rapidly growing population in Africa? Paper for the Expert Meeting on How to feed the World in 2050, Rome; 2009.

4. FAO. World fertiliser trends and outlook to 2018; 2015.

5. Vanlauwe B, Sanginga N, Giller KE, et al. Management of nitrogen fertiliser in maize-based systems in sub humid areas of Sub-Saharan Africa; 2004.

6. Chirwa E, Dorward A. Agricultural Input Subsidies: the recent Malawi experience, Oxford university press. COMESA, 2009. Getting Fertilisers to Farmers: How to do it? Who should do it? and Why it Should be Done? In: PROGRAM, FSAAM; 2013.

7. van der Velde M, See L, You L, et al. Affordable nutrient solutions for improved food security as evidenced by crop trials. PLOS ONE. 2013;8(4).

8. FAO. Fertilisers and food production: Summary review of trial and demonstration results 1961-1986. Rome: FAO; 1998.

9. Mueller ND, Gerber JS, Johnston M, et al. Closing yield gaps through nutrient and water management. Nature. 2012.

10. FAO. The State of Food and Agriculture 2015; 2015.

11. Jayne T, Rashid S. Input subsidy programs in sub-Saharan Africa: a synthesis of recent evidence. Agricultural Economics. 2013;44:547-562.

12. Minot N, Benson T. Fertiliser subsidies in Africa: are vouchers the answer? IFPRI; 2012.

13. Smaling EMA, Lesschen JP, van Beek CL, et al. Where do we stand 20 years after the assessment of soil nutrient balances in sub-Saharan Africa? World Soil Resources and Food Security. 2013.

14. Heinen H, Heesmans H, de Willigen P, et al. Predicting crop yields in tropical countries with limited data availability: the QUEFTS approach revisited Submitted to Geoderma; 2016.

15. Callan M, Davies R. When Business Meets Aid: Analysing Public-Private Partnerships for International. Development Policy Centre Discussion; 2013. 28 p.
16. WinklerPrins AMGA, Sandor JA. Local soil knowledge: insights, applications, and challenges Geoderma. 2003;111:165-170.

17. Gray LC, Morant P. Reconciling indigenous knowledge with scientific assessment of soil fertility changes in southwestern Burkina Faso. Geoderma. 2003;111:425-437.

18. Desbiez A, Matthews R, Tripathi B, et al. Perceptions and assessment of soil fertility by farmers in the mid-hills of Nepal'. Agr Ecosyst Environ. 2004;103:191-206.

19. Romig DE, Garlynd MJ, Harris RF, et al. How farmers assess soil health and quality. J Soil Water Conserv. 1995;50:229-236.

20. Corbeels M, Shiferaw A, Mitiku H. Farmers'knowledge of soil fertility and local management strategies in Tigray, Ehtiopia. Managing Africa's Soils; 200. 10 p.

21. Saito K, Linquist B, Keobualapha B, et al. Farmers' knowledge of soils in relation to cropping practices: A case study of farmers in upland rice based slash-and-burn systems of northern Laos. Geoderma. 2006;136: 64-74.

22. Ogada MJ, Mwabu G, Muchai D. Farm technology adoption in Kenya: a simultaneous estimation of inorganic fertiliser and improved maize variety adoption decisions. Agricultural and Food Economics. 2014;2(12): $1-18$.

23. Amsalu A, de Graaff J. Determinants of adoption and continued use of stone terraces for soil and water conservation in an Ethiopian highland watershed. Ecological Economics. 2007;61(2-3):294-302.

24. De Graaff J A, Amsalu F, Bodnár A, et al. Factors influencing adoption and continued use of long-term soil and water conservation measures in five developing countries. Applied Geography. 2008;28(4): 271-280.

25. Turner MD. Rethinking Land Endowment and Inequality in Rural Africa: The Importance of Soil Fertility. World Development; 2006.

26. YARA. Agri Fertiliser Handbook; 2003.

27. UN. Africa review report on waste management. Main Report, 2009, UN economic and social council, Economic commission for Africa; 2009.

28. Fairhurst T Handbook for Integrated Soil Fertility Management. Nairobi. Soil Health Consortium.

29. Sanginga N, Woomer P. Integrated Soil Fertility Management in Africa: Principles, Practices and Developmental Process. Nairobi: Ropical Soil Biology and Fertility Institute of the International Centre for Tropical Agriculture; 2009. 263 p.

30. Nkonya E. Finding a middle ground. Incentivizing adoption of Integrated Soil Fertility Management. IFPRI; 2015.

31. Lamers JPA, Bruentrup M, Buerkert A. Financial performance of fertilisation strategies for sustainable soil fertility management in Sudano-Sahelian West Africa. 2: Profitability of long-term capital investments in rockphosphate. Nutr Cycl Agroecosyst. 2015;102:149.

32. Donovan C, Wopereis MCS, Guindo D, et al. Soil fertility managementin irrigated rice systems in the Sahel and Savanna regions of West Africa, part II. Profitability and risk analysis. Field Crops Res. 1999;61(2):147162.

33. Couth R, Trois C. Sustainable waste management in Africa through CDM projects. Waste Manag. 2012;32(11):2115-2125.

34. Onduru DD, Waarts YR, Jager A, et al. Converting city waste into compost pilot Nairobi (LNV-BO-10-006-115): inventory and analysis of users, producers and markets for compost, biogas and livestock feeds in urban and eri-urban areas of Nairobi; 2009 
35. Kessler A, van Duivenbooden N, Nsabimana F, et al. Bringing ISFM to scale through an Integrated Farm Planning approach - a case study from Burundi. Nutrient Cycling in Agro-ecosystem. Special Issue on "African Eco-Efficient Solutions to Food Insecurity and Climate Change" in press and published online July 2015; 2015.
36. Soh K. Global Overview of the Fertiliser Industry including Trends and Outlook. Turnhout, Belgium: Advanced Fertiliser Technology Workshop; 2001.

37. Vanlauwe B, Descheemaeker K, Giller KE, et al. Integrated soil fertility management in sub-Saharan Africa: unravelling local adaptation. Soil. 2001;1:491-508 